\title{
HUIDOBRO: FRAGMENTOS
}

Es difícil calibrar el coeficiente nacional de la poesía de Huidobro. Uno tiende inmediatamente a negarlo de plano e incluso a dudar del interés o de la validez del planteamiento. ¿Cómo relacionar, en efecto, a Vicente Huidobro (1893-1948) con Chile de una manera que no empobrezca su poesía y no someta la significación de su obra a las restricciones de una provincia cultural? Y, sin embargo, un criterio imperioso para valorar una poesía - por lo menos mientras las patrias sigan siendo lo que son, con sus poderes y su impotencia- es el puesto que ella adquiere en un determinado sistema cultural. Es éste un lazo orgánico, sustancial, entre la obra creadora y el conjunto cultural al que pertenece. Podemos ampliar la región y no hablar de cultura nacional, sino latinoamericana; pero ello vuelve a exigir la presencia de un territorio, de una sede para el cántico. Todo universalismo es al principio cosa local, pues es siempre de una tierra determinada de donde levanta vuelo el cuerpo con sus alas a cuestas. Cervantes es, ya lo sabemos, la Mancha y su más allá. Y, sobre todo, los múltiples poetas periféricos, olvidados o desconocidos, patentizan la misma experiencia. ¿Qué decir de Kalidasa, el «esclavo de Kali», cuyo Sakuntala pudo enamorar a Goethe precisamente por sus colores hindúes y brahmánicos? ${ }^{1}$. Es un clásico de otro tiempo cuyo estudio enseña mucho sobre las funciones de la tradición cultural en una formación social tan diferente a la europea. Y Lucien Blaga, el admirable poeta rumano de este siglo, excluido hasta hace poco de las jerarquías artísticas de Occidente, muestra hasta qué punto los «acentos rumanos» pueden ser potenciados líricamente y captados también con lucidez intelectual ${ }^{2}$.

1 Walter Ruben, Kalidasa. The Human Meaning of his Works (Berlin: Akademie-Verlag, 1957).

${ }^{2}$ Véase la reciente antología bilingüe, en rumano y francés: Lucien Blaga, Poeme-Poèmes (Bucarest: Editura Minerva, 1974). Blaga es también autor de un admirable ensayo: Trilogia culturii (1.* ed., 1935; Bucarest, EPLU, 1969), donde, 
En el caso de Huidobro, dos obstáculos se oponen ciertamente a la empresa de definir su sitio nacional. Primero porque casi siempre se ha visto en él a un representante del costado cosmopolita de nuestra cultura. Es claro que el mismo poeta enfatizó conscientemente este aspecto de su personalidad intelectual, haciéndolo a veces de forma agresiva no tanto contra la sociedad que le dio origen, sino contra la clase alta que lo parió. Lo demuestran muy bien las cartas a su madre, escritas en su mayor parte desde París por los años 1930 y siguientes. Ellas revelan a la vez a una madre muy posesionada de su rol de ama de clase, aunque lo suficientemente perspicaz para advertir lo que había de frágil en algunas actitudes de su hijo. Es muy curioso que algunas invectivas que se hallan en el poema «Aquí estoy», de Neruda, guarden a veces similitud literal con vengativos reproches de la madre. Ello habla de lo extendido de una leyenda antihuidobriana en el primer quinquenio de los $30^{3}$.

En lo anterior está de por medio la noción utilizada para dar cuenta del asepcto cosmopolita de su obra, la noción de vanguardia. Si bien como categoría histórico-artística, y especialmente para los movimientos estéticos de este siglo, ella conserva una validez firme, aunque relativa, es evidente por otro lado que la articulación social del vanguardismo fue peculiar en cada país. El caso del futurismo en la Rusia leninista y en la Italia prefascista es el más conocido y dilucidado por su vínculo con las opciones prácticas de aquellas sociedades ${ }^{4}$. En América Latina, con todo, ello no resulta menos verificable. En cuanto a Chile, país que careció a comienzos de siglo de un modernismo propiamente tal, vemos también que su vanguardia confluye muy pronto hacia proyectos específicos correspondientes al momento histórico y a las coyunturas culturales. Es el delta en que desemboca el grupo formado en torno a las revistas $A z u l$ y Musa Joven. Progresiva criollización de la poesía de Pablo de Rokha, repliegue intimista de Angel Cruchaga después de 1920: en estas inflexiones también hay lugar para Huidobro, cuya singularidad tratamos de aprehender. Opciones divergentes, por lo demás,

entre otras consideraciones filosóficas sobre el tiempo, expone su idea del «horizonte miorítico» como un rasgo de la cultura rumana.

${ }^{3}$ Cartas cruzadas entre Huidobro y su madre, alrededor del año 1930. La mayor parte pertenecen a ella. La microcopia, que no tengo a mano, me fue obsequiada por el señor Mauricio van de Maele, cónsul de Bélgica en la ciudad de Valdivia, Chile.

${ }^{4}$ Simposio sobre el futurismo ruso, organizado por Jean Pérus, director del Centre d'Études Slaves de la Universidad de Clermont, a comienzos de enero de 1974. 
que coexisten en un precursor como Pedro Prado, cuya relación con la vida nacional es muy clara, como lo es también su indudable contribución a la formación de una lírica nueva ${ }^{5}$. Diferencias de peso cultural específico se advierten comparando a Huidobro con Rosamel del Valle, por ejemplo ${ }^{6}$. La distancia entre sus dos obras no radica únicamente en sus respectivas objetivaciones (temperamentos poéticos, estilo, temas, líneas estéticas que las influyen), sino en el nexo cultural que ellas establecen, presididas una por la ecuación y otra por el desequilibrio de las fuerzas centrípetas y centrífugas que las habitan. Con la excepción iluminadora de Rosamel del Valle, en todos los demás poetas vanguardistas lo nuevo es herramienta de averiguación de lo propio, excavación de vestigios, aventura de un orden arqueológico. Que Alsino (1920), el campesino jorobado, y que Altazor (1919-1931), el profeta sin tierra, levanten vuelo al mismo tiempo resulta más que una sugerente coincidencia en nuestra vida nacional ${ }^{7}$. Sus autores tratarán de integrarse en el curso de la historia - de aterrizar - cuando ésta se haga candente en el país alrededor del año $1925^{8}$.

Justamente de aquí deriva otra dificultad, pues el arranque y el crecimiento de la producción más importante de Huidobro se llevan a cabo en un período, indeciso primero y luego turbulento y complejo, en el desarrollo de Chile. Es un lapso que va desde el umbral de la renovación política alessandrista, pasando por dictaduras militares (Carlos Ibáñez: 1927-1932) y por una lucha social todavía inorgánica (fugaz República Socialista, en 1932), hasta el triunfo de las fuerzas de centroizquierda con el Frente Popular (1938). La muerte de Huidobro ocurre en un año en que reina la represión contra el pueblo de Chile (1948). Lo raro y lo característico de su figura cultural es que parece estar ausente con su silencio y en su muerte de las victorias y las tragedias de sus compatriotas.

Hay índices sensibles, casi materiales, que ayudan a perfilar este orden de dificultades. A Neruda se le conoce y se le recuerda en fotografías precisas, desde ese adolescente de manos interminables hasta

${ }^{5}$ Véase, de René de Costa, «Prólogo a su edición de Pedro Prado, El llamado del mundo (Santiago: Editorial Universitaria, 1971), pp. 9-14.

- Orfeo, primer libro de Rosamel del Valle, es de nombre revelador. Su leve diferencia, pero diferencia al fin, con un título como Adán pone de relieve lo que decimos.

7 El tema del vuelo adquiere presencia y realce por estos años. En sus lecciones de la Universidad de Concepción, Gastón von dem Bussche dedicó acertadas observaciones a Los pájaros errantes, de Prado.

${ }^{8}$ Véase Carlos Vicuña, La tirania en Chile (Santiago, 1938). 
aquel rostro impresionante, ya carcomido por el tiempo, que nos mira desde el ataúd, desde el fondo de tinieblas del país. Estas fotos se imponen incluso al contacto personal que con él se pueda haber tenido. Huidobro, en cambio, para quienes nunca le vimos, no coincide con sus fotos, con ésa, por ejemplo, que circula en la sobrecubierta de sus Obras completas y que sólo nos remite a la insigne insignificancia de la clase alta chilena. Por el contrario, él se nos revela más bien -y fue un acierto de René de Costa el habérnoslo recordado- en el retrato leve y poderoso trazado por la mano de Arp. Retrato que es en verdad máscara, una máscara hecha de aire y de frente deslumbrada. ¿Cabeza angélica tal vez o croquis solar de alguien liberado para siempre de su solar? «Et ma tête s'éloigne de mon corps», escribiría el poeta en 1917 en el poema «Rue».

Por otra parte, si los viajes diseñan la biografía poética de Huidobro, lo hacen de un modo extraño. Gabriela Mistral fue también viajera -y mucho-, pero sus movimientos tienen algo de soberana solidez. Son largas estancias, poderosas instalaciones bajo el sol del Mediterráneo, de Brasil o de California, o en parajes del frío, sean ellos la Patagonia o Nueva York. Allí se mudaba de valles con majestad cordillerana. También los viajes de Neruda, más allá de su residencia asiática, poseen una límpida regularidad; son «navegaciones y regresos» si se los compara con los desplazamientos nerviosos, vibrátiles, que caracterizan a Huidobro. El affaire de Irlanda (1923), el rapto y la fuga con su amada desde Santiago (1925), su indesentrañable participación en la guerra civil española, son hechos inaprehensibles, unidos sólo en la caprichosa geografía de sus viajes, cuya fórmula se nos escapa porque no pertenece a la esquiva realidad, sino al reino de la leyenda. En Huidobro, el nomadismo es pulsión; sus transhumancias marinas proceden del fondo del deseo. Por eso el símbolo armonioso de las golondrinas es más bien un ansia y un anhelo, y no la proyección de su íntima verdad transatlántica. Es el vaivén, ése de las golondrinas, purificado de todo; sin mar, sin tierra; sístole y diástole de una circulación planetaria. Es el pulso sin el lastre del cuerpo.

$\mathrm{Y}$ es que, para el Huidobro real, el viaje siempre fue desgarramiento, tensión, encrucijada: conciencia corpórea de su situación cultural. Horizon carré (1917) y Poemas árticos (1918) meditan esencialmente esta circunstancia, que es la circunstancia de Huidobro. El tema se prolonga mucho más allá, cubriendo obsesivamente la totalidad de su poesía. En 1918, invirtiendo el asunto apollinairiano del «Emigrante a América», escribe: 


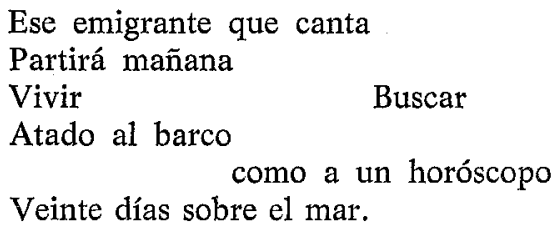

En el poema «Astro», también de Poemas árticos, el poeta se nos muestra inclinado sobre su página blanca en una alcoba que comienza a navegar. El bateau ivre de Huidobro no se detiene nunca; lo sabíamos ya desde 1916, con «El espejo de agua», en que había definido su propia identidad como algo inquieto, para siempre móvil. Pero también mucho más tarde, en su gran poema «Temblor de cielo» (1931), el poeta rezará al «azar» en una plegaria que es casi una utopía existencial:

Así, esperando el gran azar.

Que el polo norte se desprenda como el sombrero que saluda.

Que surja el continente que estamos aguardando desde hace tantos años, aquí sentados detrás de las rejas del horizonte.

Jaula del destino, prisión tras el horizonte que se ha cerrado: así es como siente Huidobro, más acá de las golondrinas, la condición de su ser cultural.

\section{NOMBRES, SÍMBOLOS, IMÁGENES}

En la identidad de sus libros, en numerosos símbolos, en imágenes que afloran, se pierden y vuelven a encender su poesía, Huidobro nos comunica, con pena y a la distancia, el sentimiento de un país ausente, de una oquedad que polariza la selección de sus materiales poéticos. Selección antipódica, como veremos, operada en confines opuestos y remotos a la situación geográfica de su lugar original. Ello no impide que una silueta borrosa vaya esbozándose a partir de esa meditación introspectiva que el poeta lleva a cabo de su situación cultural, de su origen y su destino como escritor periférico.

El título de Poemas árticos (1918) es ya revelador. Este conjunto poético, escrito por Huidobro durante los primeros años de su residencia en Francia, da a su mirada una orientación boreal. Que no hay sólo en la elección del nombre una señal de la consistencia transparente, cristalina, que el poeta atribuye a sus poemas, sino a la vez una denotación de fondo; se confirma en que el libro concluye precisamente con la pieza «Mares árticos». Hay en esta obra una geografía interiorizada. 
De todos modos, el primer hilván es importante; por cuanto en lo que toca al itinerario y a las transformaciones de los símbolos huidobrianos, nos hallamos ahora con una solidificación del mismo material, líquido y corriente, de $E l$ espejo de agua (1916). E1 «espejo» de su poesía, mágicamente convertido en arroyo, estanque y mar, se prolonga por encima de sus versos y del pequeño libro en este otro poemario, que representa un nuevo avatar del mismo elemento.

Lo ártico, con todos los armónicos secundarios que rodean su zona poética (aurora boreal, polo, hielos, norte, témpanos, esquimales), es una fijación de la patria en las antípodas, en un polo espiritual que mantiene allá una relación magnética con el otro, el de su origen material. Y ello nos conduce inmediatamente a otra área muy nítida en su poesía, cual es la proyección que en ella adquiere el diagrama de los puntos cardinales.

Desde reveladoras boutades - como ésa del inicio de Altazor: «Los cuatro puntos cardinales son tres: el sur y el norte»- hasta la elección personal o por adhesión a un nombre de revista como el de Nord-Sud, esta polarización en el esquema cardinal resulta decisiva para la biografía poética, es decir, cultural, de Vicente Huidobro. Veremos su desarrollo en Ecuatorial (1918), título que hace pendant con el de Poemas árticos y que recalca la incisión del planeta en dos mitades. Que la mente de Huidobro esté repartida en 1918 entre lo ártico y lo ecuatorial habla claramente de sus preferencias geográficas y de los exactos contornos de su ubicuidad. Así, Poemas árticos, Nord-Sud, Ecuatorial, forman una serie coherente que tiende a estatuir un espacio poético cualitativo, no homogéneo, en que la superficie de la tierra parece poblarse de valencias culturales de signo contrapuesto. La espiritualidad en esta visión no se distribuye con equidad y propende a desposeer a uno de los hemisferios en beneficio del otro, ártico y transecuatorial. Por ello el enigmático verso de Altazor: «Dejé la ecuatorial recién cortada», alude, por lo menos en una de sus asociaciones más obvias, al cordón umbilical del planeta. El vínculo con la matriz de la tierra, por una pirueta típicamente huidobriana, deja de ser nexo de unión y se convierte en la línea separatriz por excelencia. La ecuatorial resulta ser así la frontera esencial de la actual humanidad, por lo menos en la conciencia poética de Huidobro ${ }^{9}$. Los del norte y los del sur, los árticos

${ }^{9}$ Veremos, sí, que al final de Ecuatorial su sentido cambia totalmente. De frontera geográfica que era y, por tanto, de algo limitativo, pasa a ser símbolo de discontinuidad histórica, cargándose con los valores positivos de lo nuevo y del futuro. Será, allí, «la línea ecuatorial recién brotada». 
y los otros, los que viven debajo y los que viven más allá de la ecuatorial.

Todos estos signos -en los cuales sería redundante insistir, pues su poesía está llena de rastros para orientarse (brújulas, rosas de los vientos, vientos contrarios, cruz del sur y otras constelaciones, etc.) - nos conectan a la vez con el tiempo de las exploraciones, de los descubrimientos, de las travesías marítimas: todo lo cual se unificará magistralmente en el poema Ecuatorial... ${ }^{10}$.

\section{Junto a LENIN y MaLlarmé}

Para concluir, quizá sea apropiado ensayar un pequeño juego, ya que la poesía de Huidobro estimula constantemente los encuentros del azar. ¿Por qué no cotejar, "a ver qué pasa», dos poemas tan significativos como los dedicados a Lenin y a Mallarmé, uno a un creador hondamente admirado por él y otro a la mayor figura política de la época contemporánea? El Tríptico a Stéphane Mallarmé y la Elegía a la muerte de Lenin son sin duda composiciones fuera de serie que pueden valer por la obra entera de poeta.

El poema de Lenin celebra la dimensión cósmica que tienen la vida y la muerte del dirigente ruso. E1 poeta va marcando con insistencia, como en un canto reverencial, la proyección histórica del hombre que acaba de morir. Lenin, un poco como esta ecuatorial que hemos vislumbrado, corta tajantemente y unifica; corta el tiempo y unifica el mundo por encima de las «tribus» y de las «tierras hostiles»:

Has abierto las puertas de la nueva era

$\mathrm{Tu}$ estatura se levanta

Como un cañonazo que parte en dos la historia humana (...)

No hay más distancia de una tribu a otra

$\mathrm{Tu}$ voz de semilla que traen los vientos venerables

$\mathrm{Tu}$ voz Lenin cambia la raza humana

$\mathrm{Y}$ hace una sola tierra de tantas tierras hostiles.

Adviértase como sutil inflexión que es la voz de Lenin la que destaca en el homenaje del poeta. $\mathrm{Y}$ como estribillo profundo se modulará varias veces:

Contigo la muerte se hace más grande que la vida.

${ }^{10}$ Ojísimo: En el trabajo original sigue un análisis de Ecuatorial, en lo esencial coincidente con el estudio de Oscar Hahn que se publica aquí mismo. Es el eslabón ausente de estas páginas, ya en sí fragmentarias. 
Pues bien: es esta misma poética la que cerrará, cual magno epitafio, la entrada de Mallarmé en el aire de la muerte. He aquí este eco exacto:

Es la muerte que se hace más grande que la vida al llevarse un hombre de tan hondo universo.

Que sepamos, nunca en otra ocasión, aparte de estos casos egregios, repitió Huidobro tan extremada reverencia. Fueron éstos posiblemente los únicos tributos de inmortalidad, de humanidad superior, que convocó su poesía. Y es harto decidor que su homenaje junte en vívido monumento los rostros de la poesía y de la historia, las transformaciones de la creación con las transformaciones del universo social en su conjunto.

Lo mismo que el desarrollo de la Revolución francesa fue agrietando a los románticos ingleses, cuyo abanico de posiciones ante ella va desde Byron, pasando por Shelley y Keats, hasta Coleridge y la involución conservadora de Wordsworth y Southey, así también el surgimiento de los procesos revolucionarios en cuatro continentes ha ido diferenciando a la vanguardia poética entre los Byron y los Bob Southey de este tiempo («Explaining metaphysics to the tories», como de éste dijera aquél al inicio de Childe Harold). Digamos, para seguir con la analogía, que la actitud de Huidobro se parece mucho a la de un Shelley o de un Keats, distante y lejana de las luchas de su patria, pero en lo interno y en lo profundo lealmente comprometido con el espíritu de lo nuevo. Es lo máximo que le permitieron su origen de clase y la fase política de Chile en ese entonces. Es así como a través de una amplia parábola Huidobro reencuentra a su patria: mediante la conversión de una geografía cultural preexistente en una experiencia histórica cuyo sentido adivina, pues convoca en él la avidez por lo nuevo, por lo que funda radicalmente el futuro. Tal es la raíz legítima que está en la base de su vanguardismo.

University of Washington.

JAIME CONCHA 